\begin{abstract}
A dead adult harbor porpoise (Phocoena phocoena) was found on the Long Beach Peninsula in Washington on 22 August 2012. The harbor porpoise was skeletonized, with the forestomach being the only organ that remained. The forestomach contained 5 passive integrated transponder (PIT) tags and 91 coded wire tags (CWTs). The PIT tags were from juvenile Chinook salmon (Oncorhynchus tshawytscha) from 3 hatcheries in the Columbia River Basin. Of the 91 CWTs, 88 tags were identified as having come from juvenile Chinook salmon from Columbia River Basin hatcheries and 3 tags came from unidentified fish from hatcheries in Oregon. The 88 CWTs represent a number of hatcheries along the Columbia and Snake Rivers in Idaho, Washington, and Oregon. The tagged juveniles were released in the spring and summer of 2012. This report is the first one of Chinook salmon PIT tags and CWTs being recovered from a harbor porpoise in the Pacific Northwest, and it is one of few records of harbor porpoises eating salmon. The presence of these tags and the number of tags in the forestomach of a harbor porpoise indicate that juvenile Chinook salmon might be a more important component of the diet of harbor porpoises in the Pacific Northwest than previously thought.
\end{abstract}

Manuscript submitted 10 February 2019. Manuscript accepted 19 September 2019. Fish. Bull. 117:303-307 (2019).

Online publication date: 4 October 2019. doi: 10.7755/FB.117.4.3

The views and opinions expressed or implied in this article are those of the author (or authors) and do not necessarily reflect the position of the National Marine Fisheries Service, NOAA.

\title{
Salmonid passive integrated transponder tags and coded wire tags found in the forestomach of a harbor porpoise (Phocoena phocoena) in southwestern Washington
}

\author{
Dalin N. D'Alessandro (contact author) \\ Deborah A. Duffield \\ Email address for contact author: dalin@pdx.edu \\ Department of Biology \\ Portland State University \\ P.O. Box 751 \\ Portland, Oregon 97207
}

Passive integrated transponder (PIT) tags and coded wire tags (CWTs) inserted into Chinook salmon (Oncorhynchus tshawytscha) of the Columbia River Basin in the Pacific Northwest were recovered from the forestomach of a harbor porpoise (Phocoena phocoena) in 2012. Although the Columbia River Basin primarily comprises parts of Idaho, Oregon, Washington, southeastern British Columbia, Canada, and western Montana and small parts of Nevada, Utah, and Wyoming (Fig. 1), the primary areas represented by these tags include Idaho, Oregon, and Washington. The Columbia River Basin is further divided into smaller basins by the Regional Mark Processing Center as part of the Regional Mark Information System (RMIS), a collective database of records of releases of anadromous salmonids tagged with CWTs, recoveries of CWTs, and the locations of these events (available from website). Only the basins associated with tags recovered from the harbor porpoise are identified in Figure 1.

During routine beach surveillance on 22 August 2012, staff of the Northern Oregon/Southern Washington Marine Mammal Stranding Program,
Portland State University, found a $140-\mathrm{cm}$ adult harbor porpoise (Phocoena phocoena) of unknown sex on the Long Beach Peninsula in southwestern Washington (46.44191, -124.06052) (Fig. 1). The animal was heavily scavenged and skeletonized, with only the forestomach remaining of the internal organs. The skull and forestomach were collected. The entire right occipital area of the skull was fractured in a circular pattern, due to either scavenging or trauma. Examination of the forestomach contents revealed 5 PIT tags and 91 CWTs (Table 1). All tags were submitted for identification to the Oregon Department of Fish and Wildlife (ODFW) Columbia River Management Program in Clackamas, Oregon.

The PIT tags were identified as having come from juvenile fall-run Chinook salmon from hatcheries in the Columbia River Basin that were tagged in April 2012 and released in May 2012. The CWTs were from juvenile Chinook salmon that originated from Columbia River Basin hatcheries and that were from various runs but primarily from fall runs, and all tagged Chinook salmon were released in the spring and summer of 2012 (Table 2, Fig. 1). 


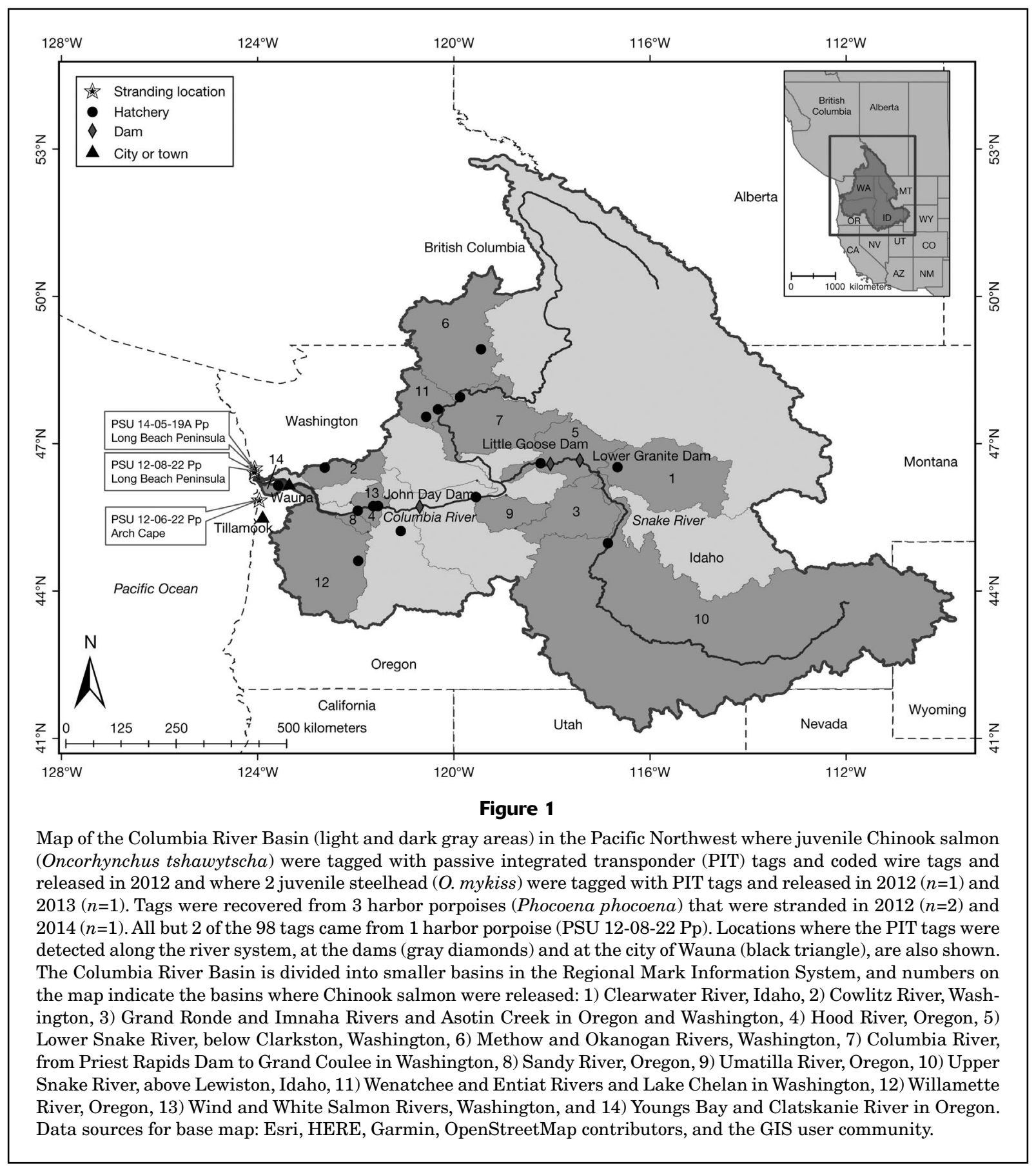

Although PIT tags and CWTs have been found in dead, stranded pinnipeds in our area, which covers the outer coast from Tillamook, Oregon, to the Long Beach Peninsula, in 10 years of responding to strandings and stomach content analysis of over 150 stomachs, only 2 other harbor porpoises were found to have salmonid tags in their stomachs. One harbor porpoise, an adult male, had 1 salmonid tag (PIT tag no. 3D9.1C2DB7C94B) from a hatchery winter-run steelhead (O. mykiss) in his stomach. This harbor porpoise (Fig. 1) became stranded on 8 June 2012 at Arch Cape, Oregon (45.85530, -123.96366).
The second harbor porpoise was also an adult male that had 1 salmonid tag (PIT tag no. 3D9.1C2DDB82D3) from a wild summer-run steelhead in his stomach. This harbor porpoise became stranded on 19 May 2014 on the Long Beach Peninsula (46.48693, -124.06025). This report provides the names of the hatcheries, stock locations, release dates, and basins associated with releases of tagged Chinook salmon and steelhead for the tags recovered from the harbor porpoises in our area. In addition, tag numbers associated with the recovered PIT tags and the CWTs are provided so that queries of the online 


\section{Table 1}

Summary of information for coded wire tags (CWTs) and the juvenile Chinook salmon (Oncorhynchus tshawytscha) from hatcheries in the Columbia River Basin in which the CWTs had been inserted. These CWTs were found in the forestomach of a dead, stranded harbor porpoise (Phocoena phocoena) recovered from the Long Beach Peninsula in southwestern Washington on 22 August 2012. The code 09blank may or may not be associated with Chinook salmon because no data are available. ID=Idaho; WA=Washington; OR=Oregon; NFH=National Fish Hatchery. Data source: Regional Mark Information System (RMIS, available from website). Stock location names are given exactly as they appear in the RMIS.

\begin{tabular}{llllrl}
\hline $\begin{array}{l}\text { Release } \\
\text { location }\end{array}$ & Stock location & Hatchery & $\begin{array}{l}\text { Run (return to } \\
\text { freshwater) }\end{array}$ & $\begin{array}{l}\text { Total no. } \\
\text { of CWTs }\end{array}$ & CWT numbers \\
\hline ID & Snake River & Oxbow Hatchery & Fall & 5 & 100201 \\
ID & Lyons Ferry Hatchery & Nez Perce Tribal Hatchery & $\begin{array}{l}\text { Late fall } \\
\text { Late fall }\end{array}$ & 6 & 220216,220224 \\
ID, WA & Lyons Ferry Hatchery & Lyons Ferry Hatchery & Lat & $220324,220325,220326,220327$, \\
& & & & 4 & 055233,055260 \\
WA & Spring Creek 29.0159 & Little White Salmon NFH & Fall & 3 & 636417,636418 \\
WA & Snake River-Lower 33.0002 & Lyons Ferry Hatchery & Fall & 13 & $055399,055404,055527,055528$ \\
WA & Spring Creek 29.0159 & Spring Creek NFH & Fall & 1 & 635273 \\
WA & Cowlitz River 26.0002 & Cowlitz Salmon Hatchery & Spring & 1 & 635776 \\
WA & Wenatchee River 45.0030 & Dryden Pond & Summer & 1 & 055364 \\
WA & Wells Hatchery & Entiat NFH & Summer & 1 & 635690 \\
WA & Methow and Okanogan & Similkameen Hatchery & Summer & 2 & 636370 \\
WA & Wells Hatchery & Wells Hatchery & Summer & 18 & $090566,090567,090582,090583$ \\
OR & Big Creek Hatchery & Big Creek Hatchery & Fall & 3 & 090571 \\
OR & Columbia River Tules & Bonneville Hatchery & Fall & 3 & 636419 \\
OR & Snake River-Lower 33.0002 & Irrigon Hatchery & Fall & 2 & 090587 \\
OR & Snake River & Irrigon Hatchery & Late fall & 5 & 090585,090586 \\
OR & Umatilla River & Umatilla Hatchery & Fall & 1 & 090526 \\
OR & Santiam River North Fork & Marion Forks Hatchery & Spring & 3 & $09 b l a n k$ \\
OR & Unknown & Unknown & Unknown & &
\end{tabular}

databases, Columbia Basin PIT Tag Information System (available from website) and RMIS, can be performed for more information. The CWT numbers also identify specific batches of fish releases.

\section{Materials and methods}

The forestomach of the skeletonized harbor porpoise was collected on 22 August 2012 and transported to the Marine Mammal Laboratory at Portland State University for analysis. The forestomach was completely desiccated; therefore, a single cut to the forestomach was made longitudinally, and the contents were removed by hand. The forestomach lining was inspected for any additional contents that may have adhered to the stomach wall, and remaining contents were gently removed with forceps. Contents included PIT tags and CWTs. All of the tags were delivered to the ODFW Columbia River Management Program, where the tags were read by laboratory staff. Staff of the ODFW provided to us spreadsheets, created in Microsoft Excel ${ }^{1}$ (Microsoft Corp., Redmond, WA), that contain hatchery-related data for individual tags. For

\footnotetext{
${ }^{1}$ Mention of trade names or commercial companies is for identification purposes only and does not imply endorsement by the National Marine Fisheries Service, NOAA.
}

any CWT records that lacked data because information was not entered into the database, we later downloaded data from the RMIS website. In addition, we queried PIT tag codes and downloaded the associated records from the Columbia Basin PIT Tag Information System website to verify that additional information had not subsequently been added to the online records.

\section{Results and discussion}

Five PIT tags and 91 CWTs were recovered from the forestomach of the dead, stranded harbor porpoise from the Long Beach Peninsula. The PIT tags came from juvenile fall-run Chinook salmon representing 3 hatcheries in the Columbia River Basin: Lyons Ferry Hatchery in Washtucna, Washington, Oxbow Fish Hatchery in Oxbow, Oregon, and Irrigon Hatchery in Irrigon, Oregon. Between 3 May and 29 May 2012, these Chinook salmon were released at 3 different locations: Lyons Ferry Hatchery; the acclimation facility at Pittsburg Landing, Idaho; and Snake River, from Salmon River to Hells Canyon in Oregon and Idaho. Two of the tagged Chinook salmon (PIT tag nos. 3D9.1C2DE01E19 and 3D9.1C2DE025DA) were released in the same group on 22 May 2012, one of which was detected at the juvenile bypass system of the Lower Granite Dam (Fig. 1) in southeastern Washington on 
Table 2

Locations and dates of releases of juvenile Chinook salmon (Oncorhynchus tshawytscha) tagged with coded wire tags (CWTs) and released from hatcheries in the Columbia River Basin in 2012. These CWTs were found in the forestomach of a dead, stranded harbor porpoise (Phocoena phocoena) recovered from the Long Beach Peninsula in southwestern Washington on 22 August 2012. Also provided are the runs of the Chinook salmon and the basins where they were released. The code 09blank may or may not be associated with Chinook salmon because no data are available. ID=Idaho; WA=Washington; OR=Oregon. Data source: Regional Mark Information System (available from website).

\begin{tabular}{|c|c|c|c|}
\hline CWT numbers & $\begin{array}{l}\text { Run (return to } \\
\text { freshwater) }\end{array}$ & Basin & $\begin{array}{l}\text { Release date } \\
\text { range }\end{array}$ \\
\hline 100201 & Fall & Upper Snake River, above Lewiston, ID & 3 May \\
\hline 220216,220224 & Late fall & Clearwater River, ID & 8 May-12 June \\
\hline $\begin{array}{l}220324,220325,220326 \\
\quad 220327\end{array}$ & Late fall & Upper Snake River, above Lewiston & 21-23 May \\
\hline 220328,220329 & Late fall & Clearwater River & 21-23 May \\
\hline 055233,055260 & Fall & Wind River, White Salmon River, WA & 13 April \\
\hline 636417 & Fall & Lower Snake River, below Clarkston, WA & 29-30 May \\
\hline 636418 & Fall & Grande Ronde River, Imnaha River, Asotin Creek, OR and WA & 29-30 May \\
\hline $\begin{array}{l}055399,055404,055527 \\
\quad 055528\end{array}$ & Fall & Wind River, White Salmon River & 11-13 April \\
\hline 635273 & Spring & Cowlitz River, WA & 26 March-2 April \\
\hline 635776 & Summer & Wenatchee River, Entiat River, Lake Chelan, WA & 25 April \\
\hline 055364 & Summer & Wenatchee River, Entiat River, Lake Chelan & 17 April \\
\hline 635690 & Summer & Methow River, Okanogan River, WA & 16 April-7 May \\
\hline 636370 & Summer & Columbia River, from Priest Rapids Dam to Grand Coulee, WA & 16-29 May \\
\hline $\begin{array}{l}090566,090567,090582 \\
\quad 090583\end{array}$ & Fall & Youngs Bay, Clatskanie River, OR & 7 May \\
\hline 090571 & Fall & Sandy River, OR & 18 May \\
\hline 636419 & Fall & Grande Ronde River, Imnaha River, Asotin Creek & 24 May \\
\hline 090587 & Late fall & Upper Snake River, above Lewiston & 22-24 May \\
\hline 090585,090586 & Fall & Umatilla River, OR & 23 May \\
\hline 090526 & Spring & Willamette River, OR & 15 March \\
\hline 09blank & Unknown & Unknown & Unknown \\
\hline
\end{tabular}

16 June 2012. A third PIT-tagged Chinook salmon (PIT tag no. 3D9.1C2DDEE358) also was released on 22 May 2012 but not as part of the same group as the 2 Chinook salmon noted previously. This third fish was detected at 2 other locations: the juvenile bypass system of Little Goose Dam in southeastern Washington on 4 June 2012 and the juvenile bypass system of John Day Dam, at the boundary of Oregon and Washington formed by the Columbia River, on 18 June 2012. The 2 remaining PIT-tagged Chinook salmon (PIT tag nos. 3D9.1C2DD706F1 and 3D9.1C2E0A858F) were not detected in other systems during their outmigration to the Pacific Ocean.

Of the 91 CWTs, 88 tags came from juvenile Chinook salmon from hatcheries in the Columbia River Basin that were released between 15 March and 12 June 2012 (Tables 1 and 2). These 88 CWTs represent 32 different tag batch numbers from 15 hatcheries located in Idaho, Washington, and Oregon. The juveniles were from fall (number of tagged fish $[n]=81)$, spring $(n=2)$, and summer $(n=5)$ runs. The Chinook salmon were from the brood year 2011, except for 2 spring-run and 3 summer-run Chinook salmon that were from the brood year 2010. The remaining 3 CWTs were coded 09blank, indicating that they were from a hatchery in Oregon with no other information available.
Each of the PIT-tagged Chinook salmon also may have had a CWT, and the CWT numbers that would have been used for these salmon (090587, 100201, 636417, and 220324 or 220325; Bumgarner ${ }^{2}$; Rosenberger ${ }^{3}$ ) did match numbers from CWTs recovered from the harbor porpoise's forestomach (Table 1). Two of the PIT-tagged Chinook salmon would have received the same CWT number (090587) because they were part of the same group $\left(\right.$ Rosenberger $^{3}$ ), and 2 tags with this CWT number were recovered from the harbor porpoise's forestomach. Given that 5 of the recovered CWTs may have come from PITtagged Chinook salmon, the minimum number of individual juvenile Chinook salmon consumed by this harbor porpoise is 86 .

On the basis of the release dates of the juvenile Chinook salmon, the date and location of the stranding of the harbor porpoise, and the migration behavior of hatchery Chinook salmon, particularly those from the fall runs that tend to

\footnotetext{
2 Bumgarner, J. 2018. Personal commun. Snake River Lab, Fish Program, Sci. Div., Wash. Dep. Fish Wildl., 401 South Cottonwood St., Dayton, WA 99328.

${ }^{3}$ Rosenberger, S. 2018. Personal commun. Idaho Power Co., 1221 West Idaho St., Boise, ID 83702.
} 
migrate in huge schools in the tributaries $\left(\operatorname{Kern}^{4}\right)$, it is possible that the juvenile Chinook salmon tagged with the tags found in the harbor porpoise had gathered in large densities at the mouth of the Columbia River before heading into the Pacific Ocean. This gathering would have made them more vulnerable to one or more foraging events by the harbor porpoise. These foraging events were likely opportunistic because literature review does not support the notion that salmonids are regular prey in the diet of harbor porpoises along the west coast of North America (Scheffer and Slipp, 1948; Wilke and Kenyon, 1952; Scheffer, 1953; Jones, 1981; Treacy $^{5}$; Gearin et al., 1994; Walker et al. $^{6}$ ). However, Treacy ${ }^{5}$ identified salmonid remains in 1 harbor porpoise recovered from the Columbia River area, and Gearin et al. (1994) identified remains of coho salmon (O. kisutch) in 1 harbor porpoise that was taken in a Chinook salmon set net in Washington.

Other than the PIT tags and CWTs in the harbor porpoise stranded in August 2012 and the PIT tags found in 2 other harbor porpoises, we have not found any salmonid CWTs or PIT tags in the more than 150 stomachs that we have examined since 2007 from dead harbor porpoises stranded within our area from northern Oregon to southern Washington. One PIT tag that had been inserted into a juvenile winter-run steelhead from a hatchery in the Columbia River Basin was recovered from the forestomach of an adult male harbor porpoise that was stranded on 8 June 2012 in Arch Cape, 30 miles south of the Columbia River plume. This steelhead came from the Oak Springs Hatchery in Maupin, Oregon, and was released in an acclimation pond of the sand trap in the East Fork Hood River in Oregon on 9 May 2012. This fish was not detected elsewhere downstream of its release site. The other PIT tag was recovered from the stomach of an adult male harbor porpoise that was stranded on 19 May 2014 on the Long Beach Peninsula, just north of the Columbia River plume. This PIT tag came from a wild summer-run steelhead that was tagged and released in Idaho on 7 September 2013. This wild steelhead was detected on 6 May 2014

\footnotetext{
${ }^{4}$ Kern, C. 2012. Personal commun. Fish Div., Oregon Dep. Fish Wildl., 4034 Fairview Ind. Dr. SE, Salem, OR 97302.

${ }^{5}$ Treacy, S. D. 1985 . Feeding habits of marine mammals from Grays Harbor, Washington to Netarts Bay, Oregon. In Marine mammals and their interactions with fisheries of the Columbia River and adjacent waters, 1980-1982, p. 149-198. NOAA, Natl. Mar. Fish. Serv., Northwest Alaska Fish. Sci. Cent. NWAFC Processed Rep. 85-04. [Available from website.]

${ }^{6}$ Walker, W.A., M. B. Hanson, R. W. Baird, and T. J. Guenther. 1998. Food habits of the harbor porpoise, Phocoena phocoena, and Dall's porpoise, Phocoenoides dalli, in the inland waters of British Columbia and Washington. In Marine Mammal Protection Act and Endangered Species Act implementation program 1997 (P. S. Hill, B. Jones, and D. P. DeMaster, eds.), p. 63-75. NOAA, Natl. Mar. Fish. Serv., Alaska Fish. Sci. Cent. AFSC Processed Rep. 98-10. [Available from website.]
}

at the juvenile bypass facility of the Lower Granite Dam in southeastern Washington and on 10 May 2014 near Wauna, Oregon.

Although Chinook salmon have been identified as prey for other marine mammals, such as the California sea lion (Zalophus californianus), Steller sea lion (Eumetopias jubatus), harbor seal (Phoca vitulina), and killer whale (Orcinus orca), in the Puget Sound region of Washington (see Chasco et al., 2017), this report is the first one of known predation of juvenile Chinook salmon by a harbor porpoise in the Pacific Northwest, adding to the knowledge of feeding habits of harbor porpoises.

\section{Acknowledgments}

We would especially like to thank C. Kern of the ODFW for providing information regarding the PIT tags and CWTs, assisting us with interpretation of tag data, and addressing other general hatchery-related questions. We are also grateful for the tag coordinators who provided data related to PIT tags. Lastly, a huge thank you to M. Hughes from the Biology Department at Portland State University for her efforts in generating the map.

\section{Literature cited}

Chasco, B., I. C. Kaplan, A. Thomas, A. Acevedo-Gutiérrez, D. Noren, M. J. Ford, M. B. Hanson, J. Scordino, S. Jeffries, S. Pearson, et al.

2017. Estimates of Chinook salmon consumption in Washington State inland waters by four marine mammal predators from 1970 to 2015. Can. J. Fish. Aquat. Sci. 74:1173-1194. Crossref

Gearin, P. J., S. R. Melin, R. L. DeLong, H. Kajimura, and M. A. Johnson.

1994. Harbor porpoise interactions with a Chinook salmon set-net fishery in Washington State. In Gillnets and cetaceans: incorporating the proceedings of the symposium and workshop on the mortality of cetaceans in passive fishing nets and traps (W. F. Perrin, G. P. Donovon, and J. Barlow, eds.), p. 427-438. Rep. Int. Whaling Comm. Spec. Issue 15. [Available from website.]

Jones, R. E.

1981. Food habits of smaller marine mammals from Northern California. Proc. Calif. Acad. Sci. 42:409-433.

Scheffer, V. B.

1953. Measurements and stomach contents of eleven delphinids from the Northeast Pacific. Murrelet 34:27-30.

Scheffer, V. B., and J. W. Slipp.

1948. The whales and dolphins of Washington State with a key to the cetaceans of the west coast of North America. Am. Midl. Nat. 39(2):257-337.

Wilke, F., and K. W. Kenyon.

1952. Notes on the food of fur seal, sea-lion, and harbor porpoise. J. Wildl. Manage. 16:396-397. 